\title{
Enhancing Science Teaching Competency among Pre-Service Science Teachers through Blended-Mentoring Process
}

\section{Supakan Buatip}

Faculty of Science, Srinakharinwirot University, Thailand, supakan.s@psu.ac.th

\section{Parin Chaivisuthangkura}

Assoc. Prof. Dr., Faculty of Science, Srinakharinwirot University, Thailand, parin@g.swu.ac.th

\section{Pinit Khumwong}

Dr., corresponding author, Faculty of Science, Srinakharinwirot University, Thailand, pinitk@g.swu.ac.th

This mixed-methods study employed an explanatory sequential design to examine the effect of the blended-mentoring supervision toward science teaching competencies. The studied group comprised 3 pre-service science teachers who were studying in the Faculty of Education at a University in Pattani, Thailand. During 4 months of science teaching practicum in Southern Thai provinces, they were supervised under the designed blended-mentoring supervision by supervisors and in-service science teachers. A science teaching competency assessment form along with semi-structured interview was used to examine science teaching competency examining from lesson plans, teaching observation notes and teaching material. Then data were analyzed in teaching-competency mean scores in conjunction with content analysis to identify the change of teaching competency. The findings revealed that the teaching competencies of the 3 pre-service science teachers were at high level with "learning management capacity" being the highest, followed by "teacher's comprehension of the taught science content and level," and "measurement and assessment ability" with 4.08, 4.07, and 3.98 mean scores, respectively. The interview and observation analysis revealed that the influencing factors of the science teaching competencies comprise pre-class mentoring, teaching observation, reflection, and technological integration for the blendedmentoring process.

Keywords: science teaching competency, pre-service science teachers, blendedmentoring process, science teaching, teachers

Citation: Buatip, S., Chaivisuthangkura, P., \& Khumwong, P. (2019). Enhancing Science Teaching Competency among Pre-Service Science Teachers through Blended-Mentoring Process. International Journal of Instruction, 12(3), 289-306. https://doi.org/10.29333/iji.2019.12318a 


\section{INTRODUCTION}

Pre-service teachers are known to have limited teaching experience and, thus, should receive full training on teacher professional experience; a teaching practicum. Such training should be mentored by a professional with more teaching experience to ensure that pre-service teachers obtain the ability to craft a lesson plan, manage a classroom and get along with other colleagues (Hudson \& McRobbie, 2004; Roehrig, Kruse \& Kern, 2007). Besides, mentoring can also help pre-service teachers to reflect and identify rooms for improvement of their potentials (Khlib-ngoen \& Nillapun, 2013). Mentoring can improve self-confidence and communication skills as well (Chesler, Single, \& Mikic, 2003; Liang, Tracy, Taylor, \& Williams, 2002; McGuire \& Reger, 2003). Given that there is a need for a systematic and consistent support system for it (Chamrat, 2016). Nonetheless, mentoring in Thai contexts is a collaboration effort between university lecturers and in-service teachers in schools. A university lecturer is usually responsible for multiple pre-service teachers operating in different schools. This means that a university lecturer, as known as supervisor, is required to periodically visit; observe; and work with a responsible in-service teacher, as known as field mentor, to co-mentor a pre-service teacher. As a result, supervisors often failed to match their schedules with that of the supervising pre-service teachers. The phenomenon is especially true in Southern Thai provinces where political unrests have made it even more difficult for the supervisors to visit the schools at the places. Consequently, the ability to fulfill the supervising roles have diminished (Weahama, Kerdtip, \& Sungtong, 2015). This difficulty has negatively impacted mentoring consistency and then decreased its efficiency (Kobrsiripat, 2005). Eventually, pre-service teachers have loss the teaching inspiration and motivation as the teaching development became inconsistent (Roadrangka \& Srisukwatananan, 2002; Buaraphan, Singh, \& Roadrangka, 2005).

Blended mentoring is a blend of face-to-face and online mentoring approaches, which takes advantage of information-technology solutions available online to assist the communication, such as instant messaging, web board, blogging, e-mail, searching, and Facebook (Nankongnaeb, 2010; Khlib-ngoen \& Nillapun, 2013). The strategy allows the parties involved to contact, consult, and share ideas with one another almost anytime and anywhere. However, the usage ratio should appropriately be adjusted between faceto-face and online supervisions and based on the actual teaching contexts of the supervisees. The ideal usage proportion of online supervision should range from -30 $79 \%$ (Allen \& Seaman, 2005). Nonetheless, previous studies on blended mentoring suggested that technological implementations often required sophisticated technological equipment constructed or designed by specialists and, hence, have made the implementations exceedingly complicated (Nankongnaeb, 2010).Furthermore, it was evident that face-to-face mentoring in former blended mentoring most likely occurred when pre-service teachers attended university seminars but on-site mentoring, where pre-service teachers were taking real classroom actions, never took place. Therefore, supervisors would only record videos and participate in online mentoring (Khlib-ngoen \& Nillapun, 2013). Opting to do so, supervisors lacked the knowledge of how actual classroom management went. One of the critical success factors of blended mentoring is for supervisors and mentors to share and reflect ideas on the teaching so that pre-service 
teachers could make proper adjustments to enhance the ongoing learning experiences (Tubsai, 2015). When supervisors ask questions, they stimulate pre-service teachers to reflect their teaching and the learning behaviors they noticed; and such reflection can help them identify their teaching strengths and rooms of improvement (Jantarakantee, 2016; Satjapiboon, 2017). Reflections and sharing ideas help pre-service teachers to select the teaching management that suits the content as they gain more insights on which instructional approach works best for which content and how to measure the students' understanding after the approach is implemented. The techniques give preservice science teachers the ability to run classes effectively (Brookfield, 1995, p. 2226; Van, 2002, p.572-590; Hattie \& Timperley, 2007, p. 81-112). Also, blended mentoring should employ less complex communication channel (Nankongnaeb, 2010). Under such conditions, the developed blended mentoring process in this study was designed to require the supervisors, field mentors, and pre-service science teachers to participate in classroom observation sessions. Reflection tools and techniques were also added in the blended mentoring to reveal advantages and limitations of learning management which will enhance a learning process of knowledge construction and development of their further instructions (Bruning, Schraw, \& Ronning, 1999, Malithong, 2008, Kitroongrueng, 2017). To ensure that the pre-service teachers have a better comprehension of the science content, appropriate teaching techniques, effective measurement and assessment, and desirable "good teacher" characteristics, we believe that with properly in-time and continue supports via blended mentoring, pre-service teachers would develop desirable teacher traits and positive attitudes throughout the preservice professional training. Positive experiences can further cultivate faith towards the teaching profession in the long run as the $21^{\text {st }}$-century pre-service teachers who will soon graduate and become professional in the future. The purpose of this study is to investigate the effects of the blended-mentoring process towards science teaching competency among pre-service science teachers.

\section{REVIEW OF LITERATURE}

\section{Blended Mentoring Process}

The process is an integration between the use of face-to-face mentoring and online consulting solutions aiming to maximize the performance of the teaching supervision. Information technology is employed as a tool for the supervision under the condition that online supervision should be from the $79-30 \%$ portion of the entire supervisory activities (Allen \& Seaman, 2005) whereas face-to-face mentoring should be the rest. Based on the condition and to ensure that the pre-service supervision is appropriate ratio by time-consuming, concise, and easy to implement; this study employed a 1:2 online vs face-to-face ratio with a flexibly adjusted ratio not to exceed 3:1 given that both the first and last supervision must be face-to-face mentoring. The main purpose of technological employment is to add a channel, e-mentoring, to assist reflection and communication (Nankongnaeb, 2010; Khlib-ngoen \& Nillapun, 2013) as doing so would allow the supervisors, field mentors, and pre-service teachers to contact, consult, and share ideas with one another virtually anytime and anywhere. When mixing it with face-to-face mentoring, supervisors and field mentors can gain crucial insights on-field obstacles as 
the pre-service teachers are facing (Ciampa \& Gallagher, 2015). This study synthesized six steps for each cycle of the blended mentoring process as follows:

1) Preparation: The supervisors, field mentors, and pre-service science teachers worked together to create the action plan; establish mutual understanding on the objectives of the mentoring process, timing, methods, and tools; and strengthen mentor-mentee relationships.

2) Pre-class Mentoring: A week before any class, the pre-service science teachers brought the lesson plans to the field mentors; participated in the face-to-face mentoring; saved the plans in Google Docs, and posted the links to Facebook for the supervisors and field mentors to approve and suggest. Moreover, others uninvolved in the mentoring could also see the Facebook links.

3) Teaching Observation: This step comprised two selective tasks:

a) Actual Teaching Observation: The supervisors and field mentors

co-observed the teaching management and recorded the field log on competencies, events, and behaviors of the pre-service teachers or students. The pre-service teachers recorded videos; uploaded them onto either YouTube or Google Drive; and posted the links on Facebook for other pre-service teachers to watch and comment.

b) Online Teaching Observation: The supervisors observed the

teaching management online by watching the links of YouTube or Google Drive videos posted on Facebook by the pre-service teachers and then recorded the field observation logs.

In each cycle of supervision, only one option will be selected. The ratio of online vs. face-to-face observations was kept between $1: 2$ and 3:1 with the first and last supervisions cycle being face-to-face as it ensured that the supervisors would gain indepth insights on what occurred in the classrooms and gave a more accurate teaching competency assessment.

4) Post-Teaching Reflection: This step comprised two selective tasks which only one will be selected for each cycle:

a) Face-to-face Reflection: The supervisors, field mentors, and pre-service

science teachers engaged in a face-to-face reflection after the actual teaching observation.

b) Online Reflection: The supervisors, field mentors, and pre-service

science teachers engaged in an online reflection on Facebook after watching the uploaded teaching videos.

5) Assessment: The supervisors and field mentors assessed the teaching and concluded the development of the pre-service teaching determining from the lesson plan and teaching management.

6) Reporting: The supervisors summarized the development, strengths, and rooms of improvement; individually shared the findings to the pre-service teachers via Google Docs; and reported the responsible staffs and administrators in the Faculty of Education.

\section{Competencies of Science Teachers}

A competency is an ability or behavior that helps a person to transform existing knowledge and skills into effective actions as targeted (McClelland, 1973; Boyatzis, 
1982; Spencer \& Spence, 1993). Hence, competencies for science teachers refer to the behaviors that science teachers demonstrate in conjunction with science contents and processes, usage strategies of scientific and technological equipment, diversity of content and standard compliant science teaching techniques, and approaches to measure and assess the learning (National Science Teachers Association, 1998, p. 1; Polrugdee, 2003; Lert-a-rom, 2006; Suksawang, 2008; Jindanurak, 2016); as well as the ability of such teachers to design a variety of learning activities, select an instructional media or tool that is consistent with the content and learners, appropriately manage a classroom or laboratory, and come up with various measurement and assessment strategies (Phuannguluam, 2003; Hongsiri, 2001). The researcher categorized competencies of science teachers into three dimensions: 1) teacher's comprehension of the taught science content; 2) learning management capacity; and 3) measurement and assessment ability.

\section{METHOD}

This mixed-methods study employed an explanatory sequential design (Creswell \& Clark, 2017). The supervisors, field mentors, and pre-service science teachers were involved in the Blended-Mentoring Process. Initially, the quantitative classroom observation data were collected and analyzed using the science teaching competency assessment form. Later, the qualitative data including competency-based observation and interview with the teachers, supervisors, mentors, and pre-service science teachers were summarized and interpreted according to specific phenomena and contexts. The qualitative study was aimed to enhance the reliability of the quantitative one. The research was conducted during December 2017- February 2018 involving three supervisory sessions.

\section{Participants}

The participants comprised three volunteer pre-service science teachers from the Faculty of Education, Prince of Songkla University who were pseudonymized as Rohana, Abdul, and Pawinee to protect the true identities.

Rohana was a pre-service science teacher majoring in Biology who was teaching at Prachasan School, a mid-size secondary school. The pre-service duty included teaching two Biology classes for Secondary 4/1 and 4/2 on three topics: "Cells and Theories," "Cellular-Level Chemical Reactions," and "Organic and Inorganic Substances." The responsible field mentor was Jintana, and the supervisor was Somsri.

Abdul was a pre-service science teacher majoring in General Science who was teaching at TonpaiPittayakan School, a large secondary school. The pre-service duty included teaching three Science classes for Secondary 3/1, 3/2, and $3 / 3$ on three topics: "Population," "Community's Environmental Problems," and "Telescope." The responsible field mentor was Prapot, and the supervisor was Somjit.

Pawinee was a pre-service science teacher majoring in General Science who was teaching at Tonpai Pittayakan School, a large secondary school. The pre-service duty included teaching three Science classes for Secondary 3/1, 3/2, and 3/3 on three topics: "Relationships of Ecological Creatures," "Solar System," and "Waxing and Waning 
Crescents." The responsible field mentor was Teacher Supa, and the supervisor was Teacher Somjit.

The sampling was purposively from schools in Songkhla, Pattani, and Narathiwat provinces. Since these schools are distinctive in contexts, being in remote locations, and affected by the political unrest; onsite supervisions were difficult.

\section{Data Collection Procedures}

1. Three attempts of blended monitoring were conducted including two face-to-face attempts and an online attempt. The pre-service teachers received face-to-face and online suggestions from the filed mentors and supervisors, respectively, on planning and classroom management a week before each class. The researcher interviewed the supervisors, field mentors, and pre-service science teachers about the lesson plan and before teaching in class using a semi-structured interview form.

2. While the pre-service science teachers were running the classes, the filed mentors and supervisors observed them through two observational methods. In both observational methods, the filed mentors and supervisors were required to record field logs on various details including the competencies, events, environments, related individuals, and their reactions. Subsequently, the main points or additional comments were written in summary consistently with the approach proposed by Bogdan \& Biklen (1998).

After learning each learning-management session, the filed mentors and supervisors utilized the science teaching competency assessment form to assess the teaching competencies and collected teaching supplements that the pre-service science teachers produced: 1) lesson plans; 2) knowledge sheets; 3) exercise and activity worksheets; and 4) post-teaching logs.

3. After every pre-service class, the researcher interviewed the supervisors, field mentors, and pre-service science teachers about the lesson plan and teaching management using a semi-structured interview form to assess the teaching competency.

4. The researcher examined science teaching competency from collected data and material by using science teaching competency assessment form in term of overall and dimensional competency mean scores. To validate the quantitative data, the analysis was further cross-checked with the qualitative data derived from the teaching observations and semi-structured interviews with the supervisors, field mentors, and pre-service science teachers.

\section{Instruments}

The instruments were employed based on the following qualitative and quantitative data-collection purposes:

1. Quantitative Dimension: The science teaching competency was evaluated by science teaching competency assessment form. It was synthesized from competencyrelated studies (McClelland, 1973; Spencer; \& Spencer. 1993), science teaching competency (National Science Teachers Association, 1998; Institute for the Institutes for the Promotion of Teaching Science and Technology, 2002; Lert-a-rom, 2006; 
Suksawang, 2008; Jindanurak, 2016), and competency assessment of science teachers (Pantić \& Wubbels, 2010). It was a 5-point rating scale from the lowest, low, mediocre, high, and highest competency levels signified by 1, 2, 3, 4, and 5 scores, respectively. This tool measures three competency factors including a teacher's comprehension of the taught science content and level, learning management capacity, and measurement and assessment ability. The index of item-objective congruence (IOC) scores was between $0.85-1.00$.

2. Qualitative Dimension: The semi-structured interview form, with 0.85-1.00 IOC scores, covers the following interview issues: A) the teacher's comprehension of the taught science content; 2) the understanding of instructional designs; C) the in-class activity organization that promotes science learning; D) the understanding towards selecting media, equipment, and knowledge sources for the activities; E) the ability to employ such media, equipment, and knowledge sources for the activities; and F) the understanding of learning measurement and assessment. The questions both focused on changes of teaching competency and why it changes.

\section{Data Analysis}

1. The science teaching competencies were analyzed, and the scores were given as criteria of science teaching competency assessment form. Then mean score for each dimension was examined to identify the competency changes influenced by each mentoring session, and interpreted to pinpoint the science teaching competency. The mean-score interpretation criteria were in range brackets from 1.00-1.50, 1.51-2.50, 2.51-3.50, 3.51-4.50, and 4.51-5.00 which signified the lowest, low, mediocre, high, and highest competency levels, respectively.

The data from observations, interviews, field logs, and videos were analyzed with content analysis and organized, classified, and concluded with analytic induction (Creswell \& Clark, 2017). The researcher employed this analytical process to periodically analyze the data and draw the conclusions where the collective findings were compared against each other to individually track the competency development of each pre-service science teacher. The researcher also conducted a cross-case analysis to examine the factors of the blended mentoring process that enhances performance on science teaching competency.

\section{FINDINGS}

The overall and dimensional mean competency scores of the three pre-service science teachers were high when implemented the blended mentoring process. Specifically, the overall mean competency scores of Rohana, Abdul, and Pawinee were 3.92, 4.27, and 3.94, respectively (Figure 1). 


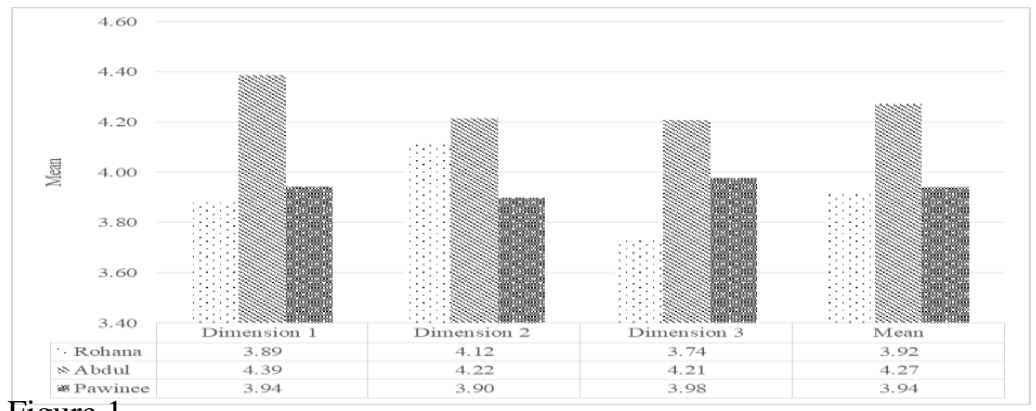

Figure 1

Mean Science Teaching Competency Scores Per Dimension with Blended Mentoring Comprehension of the Taught Science Content, Teaching Management, and Learning Measurement and Assessment

Note: Dimension 1: Teacher's comprehension of the taught science content and level

Dimension 2: Learning management capacity

Dimension 3: Measurement and assessment ability

According to Table 1, the overall competency scores suggested that all pre-service science teachers passed the required teaching competency criteria (at the high competency levels within the 3.51-4.50 range bracket). This indicated that the blended mentoring process helped enhance the science teaching competencies. Nonetheless, the tracked competency changes suggested that the competencies not consistently increase, and the influencing factor was whether the pre-service teachers have an existing knowledge or a science major related to the taught lessons. For instance, Rohana, a Biology pre-service science teacher, was tasked to teach the biology-related "Cells and Theories" for the first lesson. As a result, the teaching was assessed to have performed better than the second and third lessons: "Cellular-Level Chemical Reactions," and "Organic and Inorganic Substances," respectively due to being chemistry-related and non-biology. In summary, the mean competency scores did pass the required level but did not continue to improve, and the tasked lessons played a significant role for or against them depending on the pre-service teachers' existing knowledge, field expertise, and preparation duration (Figure2).

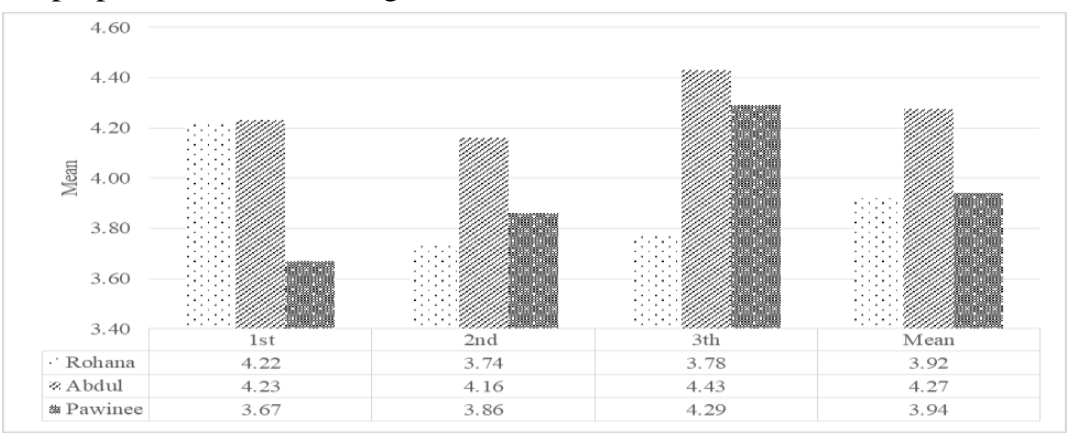

Figure 2

Mean Science Teaching Competency Scores Per Teaching Attempt 
The researcher employed a cross-case analysis to determine the blended mentoring factors that influenced the science teaching competencies of the three pre-service science teachers. The instruments for this analysis were semi-structured interview form and teaching observation form. The collected data were concluded as follows:

1. Pre-class Mentoring: Before the classes began, all field mentors held face-to-face mentoring sessions for their responsible pre-service science teachers to discuss the designed lesson plans. Later, the pre-service science teachers made the adjustments as recommended, uploaded them onto Google Docs, posted the links to Facebook for the designated supervisors and field mentors to approve or comment. The field mentors did not give any comment again on Facebook as they believed enough comments were already given during the face-to-face mentoring sessions, whereas the supervisors contrarily did so. This phenomenon is beneficial because, previously, supervisors did not have the opportunity or role to join a pre-class mentoring. The reason it is positive is that the supervisors had the opportunity to help validate the correctness and appropriateness of the teaching contents. When the instructional designs were examined by the supervisors and field mentors, their accuracy improved, and when the instructional designs were approved, the pre-service teachers would gain a better understanding on the taught contents and levels; be able to management the learning experience more effectively, and measure and assess the learning outcomes more accurately.

In Rohana's case, for instance, the self-designed lesson plan of Organic and Inorganic Substances was reviewed by Jintana, the responsible field mentor. Rohana received the feedback suggesting that "she should learn more about the topic and content before she can design an effective lesson plan which partly deals with the content composition and activity selection." Afterward, Rohana uploaded the amended lesson plan to Google Docs posted the link to Facebook for a further review by her supervisor, Somsri, before implementing it in the upcoming class.

At this stage, Somsri reviewed the lesson plan and commented that "The content was vague. If inorganic substances are anything that is non-carbon composites, is $\mathrm{CO}_{2}$ an organic substance?". Based on the data, when the comments from field mentor and supervisor went in a congruent direction, the teaching competency improved. After receiving Somsri's feedback on Facebook, Rohana made another change to make her lesson content more accurate and concise. Finally, another Google Docs link of the improved revision was posted on Facebook for Somsri's approval, and the final comment was "I think it is a good lesson plan. Try it out and share your experience."

It can be concluded that the pre-class mentoring gave the pre-service teachers a crucial opportunity to learn from their supervisory staffs and the feedbacks helped them gained a better comprehension of the taught science contents and levels. Rohana stated that “After receiving Somsri' feedbacks, I fixed my content right away. Initially, I wrote the content only about inorganic substances. However, when I learned from Somsri that my content was vague and did not cover every aspect of the taught content, I added another content on organic substances which makes the lesson covers greater learning aspects."

International Journal of Instruction, July $2019 \bullet$ Vol.12, No.3 
Pre-class mentoring is an essential step to enhance the teaching competency and it was evident in Rohanna's case that Somsri, the supervisor, wrote a comment in Google Documents and posted to Facebook stating that "The organized activities should promote the opportunity for the students to examine and verify the content so that they can acquire essential pieces of evidence to draw a conclusion by themselves. Moreover, the students should be given the time to use and expand the new knowledge through further activities". Based on the given feedback, Rohana made changes to the lesson plan by dividing the students into groups to play a game called "Faster Than $3 G$ ", find vocabularies and functions of microscope components, and present their work results using the Gallery Walk technique.

Simultaneously, pre-class mentoring also helped improve measurement and assessment ability. This was evident in the case of Pawinee as she brought her lesson plan on "Waxing and Waning Crescents" to her field mentor, Supa, for a review. Supa commented that "The measurement and assessment approach for the students should cover the learning objectives." Also, the supervisor, Somjit, suggested that "Students' learning should be evaluated using interval questioning."

Pawinee, the pre-service teacher, stated during her interview that "When I received Somjit's suggestions, I immediately made a change to the plan. I realized that the measurement and assessment did not match the learning objectives or activities because I was not thorough enough." Based on the suggestions, it was evident that Pawinee had added a question-response assessment for the students and her measurement became more consistent with the learning objectives. Hence, it is clear that pre-class mentoring by the field mentors and supervisors had helped the pre-service science teachers with their lesson plans. The data revealed that their comprehension towards the taught science content and level, learning management capacity, and measurement and assessment ability improved. With the online-mentoring integration, the supervisors had the opportunity to follow-up and advise their pre-service science teachers despite being remotely away.

2. Teaching Observation: It was indicated that during teaching observations stage the supervisors observed the teaching sessions of all case studies using the discussed ratio range which is online vs. face-to-face between $1: 2$ and 3:1 with the first and last observations being face-to-face. The study discovered that when the supervisors employed both types of observation, they yielded no significantly different observation results. As for the field mentors, the face-to-face observation was the only employed measure.

After Rohana ran her lesson on "Cellular-Level Chemical Reactions," Jintana, the field mentor, joined an observation session which was face-to-face. She commented that "Rohana vaguely explained and summarized the experimental results because the taught content was not consistent with her field or the content was not her specialization. Also, the steps of the experiment were not congruent with the designed lesson plan. More importantly, she could not yet control the class." Simultaneously, Somri, the supervisor, observed the teaching online by watching the YouTube link via Facebook which was online. She commented that "The pre-service science teacher failed to follow the lesson 
plan when running her learning activities, neglected to use the scientific process skills, and could not systematically use the scientific equipment. As a result, the students lacked discipline during the activities. Moreover, when Rohana explained the content, she did not make the necessary content connections nor had an accurate understanding of cellular-level chemical reactions. When compared with the other topic, "Cells and Theories," she performed better at explaining the content as her existing knowledge contributed to the efficiency."

In this case, both the face-to-face and online teaching observations led the field mentor and supervisor to a similarly congruent opinion towards the teaching competency of the pre-service teacher. Moving on to the case of Pawinee which dealt with the topic, "Solar System," the posted video on Facebook was not immediately viewed by Somjit due to scheduling difficulty. Instead, it was viewed a week later from the post date, and Somjit stated during the interview that "Although it was not possible to observe the teaching via Facebook on time, the video remains there and can be subsequently viewed and this facilitates the supervising duty."

According to this phenomenon, blended mentoring allowed the supervisor to observe the teaching even though it took place approximately a week ago. This helps the supervisor to gain insights on the actual pre-service teaching environment; whether the teaching went according to the designed lesson plan; and if the pre-service teacher was able to demonstrate the science teaching competency. More importantly, the supervisor was able to do all this without having to physically appear in the classroom every time. Nonetheless, the video clip might not disclose all angles of facts on how the activities went.

3. Post-Teaching Reflection: This contained two selective tasks:

a) Face-to-face Reflection: After the face-to-face teaching observation, the supervisors and field mentors initiated this face-to-face session.

b) Online Reflection: After viewing the Google Drive or YouTube videos on Facebook, the supervisors and field mentors initiated this online session.

The findings revealed that the reflections produced by the supervisors and field mentors during the face-to-face reflections were beneficial to the enhancement of science teaching competency, e.g., classroom management, measurement and evaluation, and content elaboration. Regarding online reflection, only the supervisors took part in advising the pre-service teachers. The feedbacks highlighted matters such as teachingplan consistency, content elaboration, media and equipment usage, and opportunity allocation for students' presentations. It can be seen that both face-to-face and online reflections were equally helpful in providing the supervisors, field mentors, and preservice science teachers convenient access to the teaching reflections anywhere and anytime.

In the case of Rohana with the "Cellular-Level Chemical Reactions" lesson, Somsri reflected on Facebook that "The classroom management was not as successful yet. Today's students lack manners, do not pay attention to the class, and talk too much and too loudly. Teachers should have management strategies to control them. Otherwise, it 
will be difficult to teach a lesson. When that happens, the class will become less meaningful and will only continue to waste time just for the period to end" After receiving the feedbacks from the supervisors and field mentors, Rohana made some adaptations to her next lesson, "Organic and Inorganic Substances." The strategies included diversifying the activities and giving a more unambiguous assignment for the students to do which is filling out the worksheet while watching the video on organic and inorganic substances. As a result, the students remained focused on their video. Stimulating the students to engage in raising opinions also helped Rohana gain better classroom control. Furthermore, she also managed to explain the content more accurately. Based on the designed blended mentoring process, after a face-to-face teaching observation, the pre-service science teachers were required to post the videos on Facebook for the supervisors to add feedbacks and exchange ideas as a group. It was found that the supervisors gave the feedbacks similarly to the ones previously given during the face-to-face reflections. Therefore, it is safe to acknowledge that the blended mentoring process can rely on its reflection stage to improve the teacher's comprehension of the taught science content and level as the stage helps the pre-service science teachers to examine their strengths and weaknesses. After dealing with the identified weaknesses, it was evident that the pre-service science teachers consequently elaborated the content more accurately. Furthermore, supervisors can offer their inputs after watching an online observation posted on Facebook which gives pre-service science teachers another opportunity to engage in a group exchange. They can also come back to read the comments and complete the checklist for their next lessons. Nonetheless, according to this study, there remained some topics the pre-service science teachers would need to learn more to ensure optimum content accuracy.

4. Technological Integration: The findings discovered that every pre-service teacher in this blended mentoring implementation is well familiar with Facebook. All of them indicated congruently that it is a convenient and existing platform available for use without having to create a new website. Checking Facebook has already been their daily routines. Also, it is an ideal platform to share ideas, submit lesson plans, and upload teaching videos. More importantly, it gives users the ability to comment on the ongoing discussions right away. Adding to the list, Google Docs is another solution that allowed the pre-service science teachers to upload and share their lesson plans with their classmates, field mentors, and supervisors who were the members of the designated Facebook group. While mostly using Facebook, in some occasions, the supervisors also gave feedbacks using Google Docs. Regarding video uploads, the pre-service science teachers opted to use the solutions they were familiar with which were either YouTube, Google Drive, or directly on Facebook. The produced links were then posted on Facebook for further discussions.

\section{DISCUSSION AND CONCLUSION}

The blended mentoring process was highly efficient to enhance the teaching competencies both generally and dimensionally. On the teacher's comprehension of the taught science content and level, the pre-service science teachers demonstrated a better understanding when producing and organizing the lesson contents. In terms of the 
learning management capacity, the students received more participatory and engaging learning activities which gave them the opportunity to discover, examine, and create bodies of knowledge by themselves. As for the measurement and assessment ability, various measurement and assessment designs were adopted. However, the study discovered that this competency dimension did not improve in a consistent manner. The reason was due to the lack of specialization concerning the delivered lessons. When the lessons did not match the pre-service science teachers' field of expertise or existing knowledge, the activity organizations, media uses, demonstrations, and content summarizations became limited (Lederman, Gess-Newsome, \& Latz, 1994; Van Driel Jong, \& Verloop, 2002; Käpylä, Heikkinen, \& Asunta, 2009; Suksawang, 2008). Moreover, the competency examination revealed the following crucial influencing factors of the blended mentoring process that were beneficial to the teaching competencies of the pre-service science teachers: Firstly, the implementation of the blended mentoring process was able to build up the confidence for the pre-service science teachers before teaching as the supervisors played a significant counseling role online via Facebook. This pre-class mentoring role was missing in the past. With this implementation, the supervisors were given another opportunity to discuss with the preservice science teachers despite being far away. The finding is consistent with Roadrangka \& Srisukwatananan (2008) stating that supervisors can influence preservice teachers through counseling which is essential for their teaching development and them to eventually become a better teacher. Nonetheless, this study discovered that it was not necessary for the field mentors to conduct a pre-class mentoring via the online platform as the pre-service science teachers were already in close consultation them. Secondly, the teaching observation allowed the supervisors and field mentors to acquire the personality and behavior data of the pre-service science teachers and students while they were engaged in classroom activities. These environmental insights helped the supervisors and field mentors to identify the strengths and weaknesses of their preservice science teachers (Weahama, et al., 2015; Maitreepan, Kerdtip, \& Chookamnerd, 2015). Uploading the teaching videos to YouTube or Google Drive and posting the links to Facebook gave the supervisors the opportunity to conduct the classroom observations online so that they could assess and address the teaching competencies as if they were actually sitting in the classrooms. The benefits of the online teaching observation strategy are 1) supervisors can observe the classes more frequently without having to physically show up to the schools and save the traveling expenses (Pauschenwien et al., 2006); 2) supervisors and pre-service teachers can always come back to watch the teaching videos as the system is easily accessible, convenient, and less time consuming (Jason, 2004; Jeff, 2008; Angsopa, 2013); and 3) the videos can be viewed without limitation of time or place (Vrasidas \& Zembylas, 2004). Nevertheless, the observations revealed that the video recording could only capture some classroom angles and not the entire classroom environment. Hence, it is essential to do both the face-to-face and online observations to gain the best possible contextual insights and teaching competency assessment outcomes. Thirdly, the post-teaching reflections gave the opportunity for the supervisors and field mentors to help the pre-service science teachers identified their teaching strengths and weaknesses. This notion is in line with Satjapiboon (2017) as reflection helped the pre-service teachers to contemplate on their 
teaching, learn from one another, and improve their teaching to fit the contexts better. With the implementation of blended mentoring which involved face-to-face and online reflections, it was found that both approaches could indifferently create impacts on the development. The findings also revealed that once any supervisory staffs participated in the face-to-face reflection, there was no further need for them to join the Facebook reflection as the duplicate tasks would yield no additional value. Posting the teaching videos on Facebook is, however, still necessary because it creates a learning channel for other pre-service teachers to learn from and use as case studies to improve their competencies. In fact, the more the pre-service science teachers participate in the online reflection, the better the teaching competencies they would have. Finally, the communication-technology solutions to be integrated into blended mentoring should not be the complicated ones (Nankongnaeb, 2010). The researcher opted to use Facebook as a platform to follow up, exchange knowledge, and give feedbacks to the pre-service science teachers because it is a multi-functional system with diverse communication features, e.g., text posting, image posting, video posting, chatting, and messaging. Also, it is an easy-to-use platform for people of the same network to securely connect and communicate (McCarthy, 2012) making it a preferred choice to establish a knowledgeexchange and interactive group (Evans, Kairam, \& Pirolli, 2010).Google Docs and Google Drive were the selected data storage and sharing solutions for their powerful accessibility (Philahorm, 2018); whereas YouTube is a social networking site that mediates video sharing that does not charge its users for privately uploading and sharing videos (Phudpong, 2015). The obtained video links from these sources can further be shared with other online social media by simply copying the link and embedding them in the desired media (Suttisinthong, 2013). The findings of this study suggested that the pre-service science teachers could quickly employ such technological solutions to submit their lesson plans and teaching videos, while their supervisors could also reflect and suggest from what they see in virtually no time.

Based on the findings, the researcher took an attempt to adjust the blended mentoring roles of the supervisors and field mentors to fit various conditions including the workload, roles, and closeness between the staffs and pre-service science teachers. As a result, the field mentors were only required to join the pre-class mentoring, teaching observation, and face-to-face reflection; whereas the supervisors were only required to join both the face-to-face and online mentoring sessions given that if ones had already joined the face-to-face mentoring for that occasion, they were no longer required to join the online mentoring. The findings also suggested that the supervisors, field mentors, and pre-service science teachers should be encouraged to join more reflection sessions.

\section{SUGGESTIONS}

\section{Application of the Findings}

1. The implementation of the blended mentoring process should include a step for process orientation and strategic requirements such as roles and responsibilities;

2. Reflection is crucial for the teaching competency enhancement and, therefore, supervisors, field mentors, and pre-service teachers should be encouraged to reflect and 
exchange ideas. To stimulate the participation, personally tag the Facebook's names of the pre-service teachers to ensure that Facebook individually notify the person(s); and 3. Employ the adapted blended mentoring process even though it no longer requires field mentors to participate in an online reflection as, alternatively, they can still participate in the assigned Facebook group, stay up-to-date, and learn along.

\section{Further Studies}

1. As the pre-service science teachers in this study participated in the reflection sessions less than desirable, a further study should conduct an in-depth study to determine a more optimal and engaging approach to effectively run the reflection; and 2. There should be a study to specifically design a new technological solution for blended mentoring, specifically, for pre-service science teachers because the Facebook's notification system is yet limited and some pre-service science teachers still missed the reflection sessions.

\section{ACKNOWLEDGMENT}

The authors wish to express the gratitude to field mentors and pre-service science teachers for their kind support and participation.

\section{REFERENCES}

Allen, I. E., \& Seaman, J. (2005). Growing by degrees: Online Education in the United States. Sloan Consortium.

Angsopa, S. (2013). A consultation and recommendation model for student teacher interns. (Unpublished doctoral dissertation). King Mongkut's University of Technology North University, Bangkok.

Bogdan, R. C., \& Biklen, S. K. (1998). Qualitative research in education: An introduction to theory and methods. Needham Heights, MA: Allyn \& Bacon.

Boyatzis, R. E. (1982). The competent manager: A model for effective performance. New York: John Wiley \& Sons.

Brookfield, S. D. (2017). Becoming a critically reflective teacher. New York: John Wiley \& Sons.

Bruning, R. H., Schraw, G. J., \& Ronning, R. R. (1999). Cognitive psychology and instruction. Upper Saddle River, NJ: Prentice-Hall.

Buaraphan, K., Singh, P., \& Roadrangka, W. (2005). Development of force and motion in third-year preservice physics teachers participating in constructivist learning activities. Songklanakarin Journal of social sciences and humanities, 2, 97-119.

Chamrat, S. (2016). STEM education on the road of socially-engaged scholarship: Game changer for future learning. Kasetsart Educational Review, 31(3), 34-47.

Chesler, N. C., Single, P. B., \& Mikic, B. (2003). On belay: Peer-mentoring and adventure education for women faculty in engineering. Journal of Engineering Education, 92(3), 257-262. 
Ciampa, K., \& Gallagher, T. L. (2015). Blogging to enhance in-service teachers' professional learning and development during collaborative inquiry. Educational Technology Research and Development, 63(6), 883-913.

Creswell, J. W., \& Clark, V. L. P. (2017). Designing and conducting mixed methods research. Thousand Oaks, CA: Sage publications.

Evans, B. M., Kairam, S., \& Pirolli, P. (2010). Do your friends make you smarter? An analysis of social strategies in online information seeking. Information Processing \& Management, 46(6), 679-692.

Hattie, J., \& Timperley, H. (2007). The power of feedback. Review of educational research, 77(1), 81-112.

Hongsiri, S. (2001). A study of science teachers' competencies in Catholic school of Chantaburi Diocese. (Unpublished master thesis). King Mongkut's Institute of Technology Ladkrabang, Bangkok.

Hudson, P., \& McRobbie, C. (2004). Evaluating a specific mentoring intervention for preservice teachers of primary science. Action in Teacher Education, 17(2), 7-35.

Institutes for the Promotion of Teaching Science and Technology. (2002). National Science Curriculum Standards. Bangkok: Karusapa Press.

Jantarakantee, E. (2016). Coaching and mentoring system model for developing science teachers' teaching practices and ability to conduct classroom action research. Journal of graduate studies ValayaAlongkornRajabhat University, 10(1), 128-141.

Jason, P. (2009). Using computers and the Internet for psychiatric nursing intervention. Toronto: John Wiley \&Sons.

Jeff, I. (2008). The use and role of technology in counseling and psychotherapy. New York, NY: John Wiley \& Sons.

Jindanurak, T. (2016). Professional Science Teachers. Retrieved June 23, 2017, from http://e-jodil.stou.ac.th

Käpylä, M., Heikkinen, J. P., \& Asunta, T. (2009). Influence of content knowledge on pedagogical content knowledge: The case of teaching photosynthesis and plant growth. International Journal of Science Education, 31(10), 1395-1415.

Khlib-ngoen, W.; \& Nillapun, M. (2013). The development of a mentoring social media technology blended model for pre-service teachers' professional experience practices. Silpakorn Educational Research Journal, 7(1), 163-176.

Kitroongrueng, P. (2017). The development of an instructional design and ability in teaching of science at the elementary level using CCTV system and reflective journal writing for the elementary student teachers' faculty of education Silpakorn university. STOU Education Journal, 10(2), 176-189.

Kobrsiripat, P. (2005). The development of the professional training curriculum in the reformed teacher training curriculum. (Unpublished doctoral dissertation). KhonKaen University, KhonKaen. 
Lert-a-rom, R. (2006). Factors affecting science teacher's competency in school under the saint Gabriel's foundation of Thailand. (Unpublished master thesis). Chulalongkorn University, Bangkok.

Lederman, N. G., Gess-Newsome, J., \& Latz, M. S. (1994). The nature and development of preservice science teachers' conceptions of subject matter and pedagogy. Journal of Research in Science Teaching, 31(2), 129-146.

Liang, B., Tracy, A. J., Taylor, C. A., \& Williams, L. M. (2002). Mentoring college-age women: A relational approach. American j. of community psychology. 30, 271-288.

Luft, A. J., \& Hewson, W. P. (2014). Research on teacher professional development programs in science. Handbook of Science Education.

Maitreepan, W., Kerdtip, C., \& Chookamnerd, W. (2015). Challenging roles of university supervisor for organizing professional practicum in teacher education. Journal of Education Prince of Songkla University, 26(2), 13-25.

Malithong, K. (2008). Educational technology and innovation. (2nd ed.). Bangkok: Chulalongkorn University Printing House.

McCarthy, J. (2012). International design collaboration and mentoring for tertiary students through Facebook. Australasian J. of Educational Technology, 28(5), 755-775.

McClelland, D.C. (1973). Testing for competence rather than for intelligence. American Psychologist. 28, 1-14.

McGuire, G. M., \& Reger, J. (2003). Feminist co-mentoring: A model for academic professional development. NWSA journal, 54-72.

Nankongnaeb, P. (2010). Development of a hybrid supervision model on apprenticed training of vocational industrial students in institutes under office of vocational education commission. (Unpublished doctoral dissertation). King Mongkut's University of Technology North, Bangkok.

National Science Teachers Association. (1993). Revitalizing teacher preparation in science- An agenda for action. Washington: National Academy Press.

Pantić, N., \& Wubbels, T. (2010). Teacher competencies as a basis for teacher education-Views of Serbian teachers and teacher educators. Teaching and Teacher Education, 26(3), 694-703.

Pauschenwien, J., Jandl, M., Riegler, A., \& Vasold, G. (2006). How to use weblogs in eSupervision. In Proceedings of the 6th International Conference on Knowledge Management I-KNOW, Graz, Austria.

Phuannguluam, S. (2003). A study of science teacher competencies of the lower secondary education level under the office of Nakhon Ratchasima provincial primary education. (Unpublished master thesis). King Mongkut's Institute of Technology Ladkrabang, Bangkok.

Polrugdee, J. (2003). Development of a form to evaluate the competencies of science teacher in junior secondary school region two. (Unpublished master thesis). Thaksin University, Songkhla. 
Philahorm, W. (2018). The developing information services by applying google drive users in the 21st century. PULINET Journal, 5(1), 50-58.

Phudpong, V. (2015). Media exposure, attitudes and adverting avoidance behaviors in youtube of Thai teenagers. (Unpublished master thesis). Burapha University, Chon Buri.

Roadrangka, V., \& Srisukwatananan, P. (2002). Problems in professional experience training of student teachers in science education, faculty of education, Kasetsart university. Kasetsart J. (Soc. Sci), 23, $11-104$

Roadrangka, V., \& Srisukwatananan, P. (2008). Field experiences; Preservice science teacher; Field experience model. Kasetsart J. (Soc. Sci), 29(1), 25-11.

Roehrig, G. H., Kruse, R. A., \& Kern, A. (2007). Teacher and school characteristics and their influence on curriculum implementation. Journal of Research in Science Teaching: The Official Journal of the National Association for Research in Science Teaching, 44(7), 883-907.

Satjapiboon, S. (2017). Supervision concepts for the development of learning management competencies in the 21st century. Silpakorn University J., 37(1), 203-222.

Spencer, L. M., \& Spencer, S. M. (1993). Competence at work, models for superior performance. New York, NY: John Willey \& Sons.

Suksawang, C. (2011). Case studies of preservice science teachers' pedagogical content knowledge development during student teaching practices. (Unpublished doctoral dissertation). Kasetsart University, Bangkok.

Suttisinthong, T. (2013). Using youtube to marketing communications of GTH film camp. Dhurakit Pundit Communication Arts Journal, 7(1), 97-118.

Tubsai, B. (2015). Collaborative coaching: improvement of teaching and learning through the reflection of professional learning community. Paper presented at the 7th NPRU National Academic Conference, Nakhon Pathom, March, 30 - 31.

Van Driel, J. H., Jong, O. D., \& Verloop, N. (2002). The development of preservice chemistry teachers' pedagogical content knowledge. Science Education. 86(4), 572-590.

Vrasidas, C. \& Zembylas, M. (2004). Online professional development: Lessons from the field. Education and Training, 466(7), 326-334.

Weahama, W., Kerdtip, C., \& Sungtong, E. (2015). Needs assessment for supervisors of pre-service teachers' professional experiences in the three southern border provinces. Academic Services Journal, Prince of Songkla University, 27(3), 24-34.

Azhar M. (2007) Level of professionalism among Islamic education trainees in practical teaching. (unpublished master thesis). Universiti Teknologi Malaysia, retrieved September 2011 from eprints.utm.my/4276/1/75215.pdf 